\title{
Driving Forces for the Spatial Reconstruction of Rural Settlements in Mountainous Areas Based on Structural Equation Models: A Case Study in Western China
}

\author{
Jia Zhong ${ }^{1,2}$, Shaoquan Liu ${ }^{1}$, Min Huang ${ }^{1,2}$, Sha Cao ${ }^{3}$ and Hui Yu ${ }^{1, *(1)}$ \\ 1 Institute of Mountain Hazards and Environment, Chinese Academy of Sciences, Chengdu 610041, China; \\ zhongjia@imde.ac.cn (J.Z.); liushq@imde.ac.cn (S.L.); huangmin2019@imde.ac.cn (M.H.) \\ 2 University of Chinese Academy of Sciences, Beijing 100049, China \\ 3 College of Geography and Environment, Shandong Normal University, Jinan 250014, China; \\ yangwj@sdnu.edu.cn \\ * Correspondence: yuhui@imde.ac.cn; Tel.: +86-189-8076-9271
}

check for updates

Citation: Zhong, J.; Liu, S.; Huang, M.; Cao, S.; Yu, H. Driving Forces for the Spatial Reconstruction of Rural Settlements in Mountainous Areas Based on Structural Equation Models: A Case Study in Western China. Land 2021, 10, 913. https://doi.org/ 10.3390/land10090913

Academic Editors: Ana Nieto Masot and José Luis Gurría Gascón

Received: 28 July 2021

Accepted: 24 August 2021

Published: 29 August 2021

Publisher's Note: MDPI stays neutral with regard to jurisdictional claims in published maps and institutional affiliations.

Copyright: (c) 2021 by the authors. Licensee MDPI, Basel, Switzerland. This article is an open access article distributed under the terms and conditions of the Creative Commons Attribution (CC BY) license (https:/ / creativecommons.org/licenses/by/ $4.0 /)$.

\begin{abstract}
Rural settlement development in mountainous areas is the key to eliminating global hunger and poverty. The spatial reconstruction of rural settlements in mountainous areas can promote rural development in mountainous areas. In this study, the Panxi area-a typical mountainous area in China-was chosen as the study area. The driving forces for the spatial reconstruction of rural settlements in mountainous areas were explored from the perspective of peasant households by combining participatory rural appraisal (PRA) with structural equation modeling (SEM). Results showed that: (1) $62.03 \%$ of the 266 peasant households included were willing to have spatial reconstruction, indicating that most peasant households in mountainous areas have a very strong intention towards the spatial reconstruction of rural settlements. (2) Infrastructure, medical conditions, living environment, farming culture, and dietary habits significantly influenced the reconstruction intention of peasant households. In contrast, development opportunities, place attachment, language, and living mode each had a slight influence. (3) Geological disasters were the main driving force for the spatial reconstruction of rural settlements in mountainous areas, whilst the driving force of living cohesion was the smallest. This study provides insights for future planning and construction of rural settlements in the Panxi area and spatial reconstruction practices. It has important practical significance for overcoming poverty and realizing rural revitalization in mountainous areas.
\end{abstract}

Keywords: rural settlement; mountainous areas; spatial reconstruction; SEM; driving forces

\section{Introduction}

Rural settlements are important places for rural population life and production and are a space phenomenon. The rural settlement space has been the research key of geographic studies concerning rural settlements [1]. With progress in urbanization and industrialization, many rural settlements face or have entered rapid transformation stages [2]. Rural transformation development is the reconstruction of rural settlement and mainly involves economic, social morphology, and spatial changes $[3,4]$. In the transformation process, the quality of many rural settlements has been improved, but 'rural hollowing and planned chaos' can coincide. These problems are particularly prominent for rural settlements in mountainous areas with complicated geological environments [5]. In previous studies, Woods (2005) emphasized the reconstruction of socio-economic formations of rural regions resulting from changes to subjects in the transformation process [6]. Li Hongbo et al. (2012) focused more on spatial transformation in rural spaces. They believed that the removal, decline, and disappearance of villages should also be considered reconstruction of rural settlements [7]. Rural space reconstruction is an important manifestation of the reconstruction of rural settlements [8], and the spatial reconstruction of rural settlements is the outlook 
of reconstructed spatial forms of rural settlement [9]. In the present study, the spatial reconstruction of rural settlements was defined in a narrow sense. That is, to adapt to the development of urban and rural areas, the process of change in the spatial distribution of rural residences is caused by changes to peasant households, which are crucial subjects of rural settlement. Whether spatial pattern changes of rural settlements are reasonable directly determines whether the rural settlement can realize comprehensive, coordinated, and sustainable development. Therefore, promoting the suitable reconstruction of rural settlement spaces in mountainous areas can improve the quality of rural settlement [10].

Exploring the driving forces for the spatial reconstruction of rural settlements is necessary and helps guarantee the effective spatial reconstruction of rural settlements. The spatial reconstruction of rural settlements is accomplished under the collaborative promotion of internal and external driving forces [11]. These include place attachment, historical culture, environment fitness, housing condition and quality, natural disasters, economic levels, infrastructure, government policies, and peasants [12-22]. The government has been the primary driver of rural reconstruction [23-25]. Although such top-down planning is characteristic of high efficiency and rapid construction [26,27], it can ignore the intentions and needs of peasant households. Thus, the outcomes of the reconstruction are not ideal [28]. As the subject of rural settlement, peasant households have the most direct and deepest needs relating to the spatial reconstruction of rural settlements. Reconstruction intention, family structure, policy cognition, risk perception, and the neighborhood of peasant households can influence reconstruction progress [29-32]. During the spatial reconstruction of rural settlements, it is necessary to combine local, practical situations [33] and consider the subjective demands of peasant households [34]. Previous studies on the driving forces for the spatial reconstruction of rural settlements have mainly concentrated on plain regions; however, there are few that have involved mountainous regions and hills [35-38]. The most common measurement models that have been used to study the driving forces for the spatial reconstruction of rural settlements are the Probit and Logit models [29,39,40]. Recently, structural equation modeling (SEM) [41] has also been applied to this area. The Probit and Logit models are used in traditional linear regression analysis. Linear regression analysis defines dependent and independent variables in the model, but it can only provide direct effects between variables and cannot show possible indirect effects. Unlike traditional regression analysis, the structural equation model can handle multiple dependent variables simultaneously and replace multiple regression, path analysis, factor analysis, covariance analysis, and other methods. This model can analyze the effect of individual indicators on the overall outcome and the relationship between individual indicators, which overcomes the limitations of the Probit and Logit models in being unable to explore internal relations among factors intuitively [42]. To date, there have been few studies from the perspective of peasant households on the driving forces for the spatial reconstruction of rural settlements in mountainous areas with complicated geological environments based on the SEM model.

Rural development is the key to achieving the new goal of sustainable development. Nearly $45 \%$ of the global population lives in rural areas of developing countries that face issues such as hunger, poverty, and youth unemployment [43]. Poverty eradication is the primary goal of the Agenda for Sustainable Development in 2030. Countries worldwide are working towards this goal and trying not to leave anyone behind [44]. Nevertheless, the number of residents in mountainous regions exposed to the risk of food shortage is increasing due to the worsening of mountainous environments, and the poverty problem in mountainous rural areas is particularly serious [45]. As a global agricultural and population power, China still had about six million rural residents across millions of rural settlements in 2017-despite the continuous acceleration of urbanization since the 21st century began. Therefore, rural settlements are still a fundamental residential form for Chinese people [46]. Mountains are extensively distributed in the continents of Eurasia and the Americas. China is also a mountainous country, with mountainous land accounting for nearly $70 \%$ of the total land area of China and the location of one-third of the population. The development of 
mountainous regions is related to poverty eradication for nearly $50 \%$ of China's population. Therefore, the development trend of rural settlements in mountainous regions directly influences the national development situation [47].

Against this background, Sichuan Province-a classical mountainous region in China characterized by poverty-was chosen as the research object. The driving forces for the spatial reconstruction of rural settlements in this mountainous area were explored by combining PRA (participatory rural appraisal) and SEM (structural equation modeling). The specific aims of this study were: (1) to combine information on the practical situations and intentions of peasant households in the study area to construct an SEM model about the factors influencing these households' intentions relating to spatial reconstruction of rural settlements; (2) to identify the major driving forces of peasant households' intentions relating to reconstruction; (3) to inform the further smooth reconstruction of rural settlement spaces in mountainous areas.

\section{Material and Methods}

\subsection{Research Area}

Sichuan Province is in Southeast China. It has high terrain in the west and low in the east, with extensive coverage by mountainous land [48]; Geological disasters frequently occur in Sichuan Province and threaten the survival and development of rural settlements and peasant households in mountainous regions. Additionally, Sichuan Province is a multiethnic province where local peasant households have diversified cultures and ways of thinking, and integrated poverty issues and ethnic-cultural problems [49]. According to relevant statistics [50], a population of 1.71 million in this province was still classified as poverty-stricken, including 5295 poor villages and 68 poor counties, in 2017. These poor regions are mainly in the western mountainous regions of Sichuan Province, which represents a severe challenge to poverty eradication. The complexity of the mountainous environment and the predominance of ethnic minorities exacerbate the difficulties in the spatial reconstruction of rural settlements in mountainous areas. In this study, the main 'battlefield' of poverty eradication in China-the Panxi area of Sichuan Province-was chosen as the study area. The Panxi area is the largest settlement area of Yi people in China. Among China's 14 contiguous destitute areas, the Wumeng Mountains are located in Panxi. The per capita net income of farmers in these areas is 2676 RMByuan, which is only half of the national average. The Panxi area is one of China's most impoverished continuous areas, with a high concentration of ethnic minorities. The urbanization rate in the Panxi area is far lower than the average national level, and there are many problems relating to rural settlements.

\subsection{Data Sources}

In the present study, data were mainly collected via a questionnaire survey prepared by the research team in January 2018. The survey period started on 25 January, 2018, ended on 3 February, 2018, and lasted for ten days. Due to language barriers, we hired four Yi college students to help us complete the questionnaire survey. The questionnaire focused on the intention of peasant households in mountainous regions relating to the spatial reconstruction of rural settlements, including the influence of housing conditions, living habits, natural disasters, and production conditions. To ensure the representativeness of the selected samples, stratified sampling and then equal probability random sampling were used to determine the research samples [51]. First, Xichang City, Miyi County, Yanyuan County, and Puge County in the Panxi area, where there are many mountain disasters and high spatial conflicts, were chosen as the sample zones based on the team's previous research results [52]. Generally, increased mountain hazards in regions with high spatial development intensity can increase the conflict between people and land. Second, eight towns with different mountain hazards and spatial conflict levels were chosen from the four sampling zones according to the coupled results of mountain hazard risk and spatial conflict [52]. Finally, two villages were chosen randomly from each sample town, from 
each of which 20 peasant households were chosen randomly according to the household register and random number table [48]. According to the above process, 16 villages and 320 peasant households were chosen. The geological positions of sampled counties and towns are shown in Figure 1.

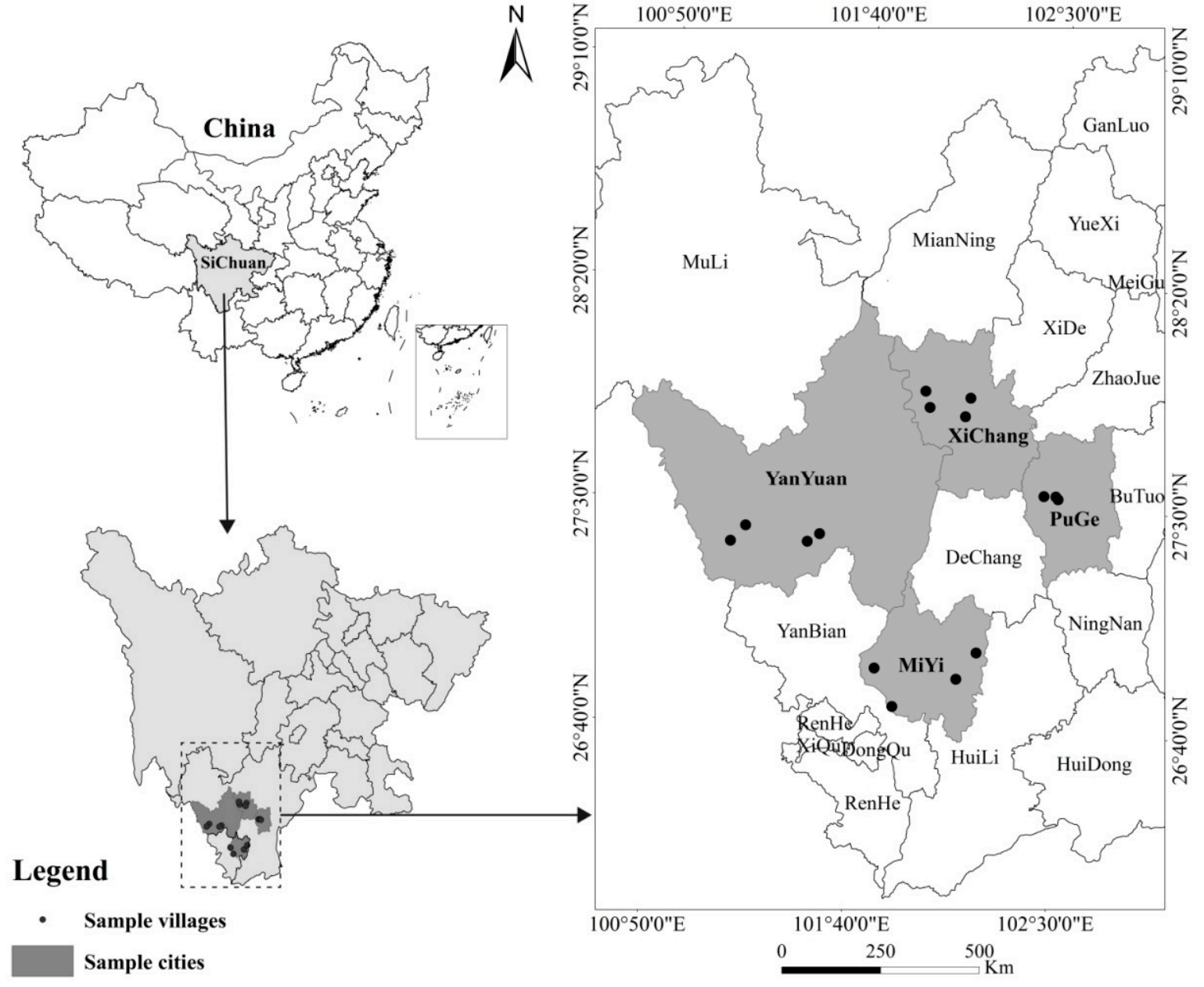

Figure 1. Location of sample cities and villages.

\subsection{Variables and Methods}

\subsubsection{Theoretical Basis}

In the 1960s, the American scholar E.S. Lee proposed a systematic theory of population migration, namely 'Push-Pull Theory' [53]. He summarized the factors affecting migration more comprehensively into four factors: a place to move in, a place to move out, intermediate obstacles, and personal factors (Figure 2). The theory is that the factors conducive to improving living conditions become the pulling force that promotes population movement, and the unfavorable living conditions of the emigration area are the pushing force. Both the immigration and emigration areas are affected by two factors: "push" and "pull". When the pushing force in the emigration area is greater than the pulling force, and the pulling force of the immigrating area is greater than the pushing force, population migration will occur [53]. When considering the relocation behavior of rural households, the possible thrust of the relocation area is primarily reflected in the occurrence of natural disasters, poor living conditions, lack of infrastructure, and information blockage in the relocation area [54-56]. Possible pulling factors in migration include many employment opportunities, a high level of education and medical care, sound infrastructure, and diverse information $[57,58]$. Possible obstacles are farmland culture, pastoral culture, and relocation 
costs $[35,59]$. Possible personal factors may be language, eating habits, ways of thinking, cultural qualities, religious beliefs, and living style preferences [14,60-63].

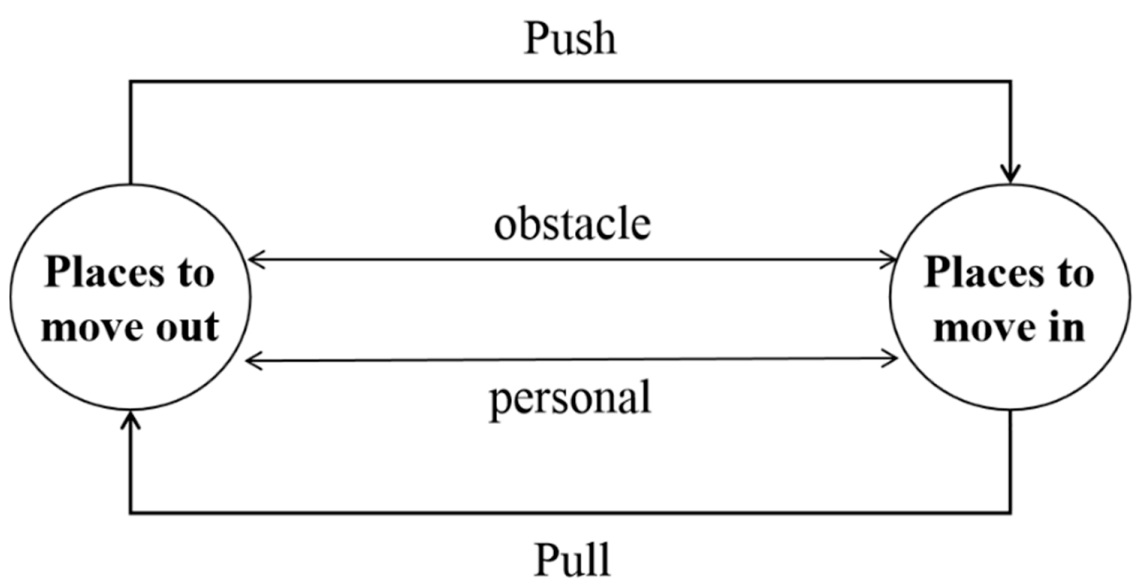

Figure 2. Push-Pull theory framework.

\subsubsection{Selection of Variables}

The intention of peasant households relating to the spatial reconstruction of rural settlements was set as the dependent variable. If peasant households were willing to reconstruct the rural settlement space, it was valued ' 0 '; otherwise, it was valued ' 1 '. As subjects of rural settlement, peasant households comprehensively consider various factors when choosing a residence, such as the surrounding natural, economic, and social environment [64-66]. These factors also collectively influence the intention of peasant households regarding reconstruction, either by promoting or inhibiting peasant household participation in the reconstruction of rural settlements.

This study explored the factors that were important in influencing the intention of peasant households relating to the spatial reconstruction of rural settlements and determined the major driving forces. Regarding the measurement method and index selection of previous studies $[54,56,65,67-69]$, and with consideration of the practical situation of the study area, five driving forces were selected. These formed the latent variables to measure household intention (Table 1) and were as follows: (1) External attractions (A1-A5): enough employment opportunities, education opportunities, a high-quality living environment, and good public infrastructure. Stronger external attractions were more appealing to peasant households from places with poor settlement conditions. (2) Geological disasters (B1-B4): geological disasters have frequently occurred in the Panxi area. When designing observation variables, questionnaires were set up from the perspectives of the perceived harmfulness of and actual past damage to property caused by geological disasters to understand the peasant households' opinions on the influence of geological disasters on settlement reconstruction. (3) Internal impetus (C1-C5): a multitude of limitations to local development in a region often motivates residents to relocate to better locations. In this study, the internal impetus was assessed from the perspectives of local traffic, water supply, power supply, signals, and the community culture and atmosphere. (4) Production cohesion (D1-D2): historically, residents in the Panxi area have mainly engaged in agricultural cultivation. Peasant households have deep connections to the land. Hence, the production cohesion of peasant households to local settlements was assessed mainly through farming and pasture culture. (5) Life cohesion (F1-F4): the Panxi area contains the highest proportion of the Yi ethnic group in China. With consideration of specific minorities, critical attention was paid to place attachment, diet, language, and living mode when measuring the life cohesion of peasant households to local settlement. 
Table 1. Driving forces affecting the reconstruction willingness of peasant households.

\begin{tabular}{|c|c|c|c|}
\hline $\begin{array}{c}\text { Latent } \\
\text { Variables }\end{array}$ & Observation Variables & Definition & Values \\
\hline $\begin{array}{l}\text { External } \\
\text { attraction }\end{array}$ & $\begin{array}{l}\text { More development } \\
\text { opportunities } \\
\text { Good living environment } \\
\text { Convenient information } \\
\text { acquisition } \\
\text { Sufficient water and power } \\
\text { supply } \\
\text { Good medical conditions }\end{array}$ & $\begin{array}{c}\text { A1: If there are more development opportunities in } \\
\text { other places, are you willing to move? } \\
\text { A2: If there is a good living environment in other places, } \\
\text { are you willing to move? } \\
\text { A3: If it is more convenient to obtain information in } \\
\text { other places, are you willing to move? } \\
\text { A4: If other places have sufficient water and power } \\
\quad \text { supply, are you willing to move? } \\
\text { A5: If there are good medical conditions in other places, } \\
\text { are you willing to move? }\end{array}$ & $\begin{array}{l}\text { Nominal variable: } \\
\text { yes }=0 ; \text { no }=1\end{array}$ \\
\hline $\begin{array}{l}\text { Geological } \\
\text { disasters }\end{array}$ & $\begin{array}{l}\text { Probability of geological } \\
\text { disasters } \\
\text { Frequency of geological } \\
\quad \text { disasters } \\
\text { Influences of geological } \\
\text { disasters on crops } \\
\text { Economic loss caused by } \\
\text { geological disasters } \\
\end{array}$ & $\begin{array}{l}\text { B1: If there is a possibility of geological disasters in your } \\
\text { current residence, you will move to another place. } \\
\text { B2: If the signs of geological disasters in your current } \\
\text { residence become more and more obvious, you will } \\
\text { move to another place. } \\
\text { B3: If geological disasters damage the crops, you will } \\
\text { move to another place. } \\
\text { B4: If geological disasters cause economic losses to your } \\
\text { family, you will move to another place. }\end{array}$ & $\begin{array}{c}\text { Ordered categorical } \\
\text { variable: } \\
1 \text { = strongly agree; } \\
2 \text { = agree; } 3 \text { = ordinary; } \\
4 \text { = disagree; } \\
5 \text { = strongly disagree. }\end{array}$ \\
\hline $\begin{array}{l}\text { Internal } \\
\text { impetus }\end{array}$ & $\begin{array}{c}\text { Power shortage } \\
\text { Poor communication } \\
\text { network } \\
\text { Weak community culture } \\
\text { atmosphere }\end{array}$ & $\begin{array}{c}\text { C1: If the road from your village to the town is difficult, } \\
\text { are you willing to move? } \\
\text { C2: If there is a water shortage in your current residence, } \\
\text { are you willing to move? } \\
\text { C3: If there is an electricity shortage in your current } \\
\text { residence, are you willing to move? } \\
\text { C4: If you are often unable to get through on the phone } \\
\text { in your current residence, are you willing to move? } \\
\text { C5: If your neighbors in the village are not } \\
\text { well-educated, are you willing to move? }\end{array}$ & $\begin{array}{l}\text { Nominal variable: } \\
\text { yes }=0 ; \text { no }=1\end{array}$ \\
\hline $\begin{array}{l}\text { Production } \\
\text { cohesion }\end{array}$ & $\begin{array}{l}\text { Farming culture } \\
\text { Pasture culture }\end{array}$ & $\begin{array}{l}\text { D1: If there is no land for farming in other places, are } \\
\quad \text { you willing to move? } \\
\text { D2: If there is no place to keep poultry in other places, } \\
\text { are you willing to move? }\end{array}$ & $\begin{array}{l}\text { Nominal variable: } \\
\text { yes }=0 ; \text { no }=1\end{array}$ \\
\hline Life cohesion & $\begin{array}{l}\text { Dietary habit } \\
\text { Language }\end{array}$ & $\begin{array}{l}\text { F1: If there are many relatives and friends in your } \\
\text { current residence, are you willing to move? } \\
\text { F2: If other places do not have your current staple food, } \\
\text { are you willing to move? } \\
\text { F3: If nobody speaks the same language as you in other } \\
\text { places, are you willing to move? } \\
\text { F4: If a new house in other places cannot meet your } \\
\text { current living mode, are you willing to move? }\end{array}$ & $\begin{array}{l}\text { Nominal variable: } \\
\text { yes }=0 ; \text { no }=1\end{array}$ \\
\hline
\end{tabular}

\subsubsection{Research Hypothesis}

Many previous studies have identified natural disasters as having important influences on the spatial reconstruction of rural settlements. For example, Filippova (2020) and Garakani et al. (2020) found that flood accidents caused significant damage to the houses and farmlands of rural residents, thus forcing post-disaster reconstruction of the villages [70,71]. Vaculisteanu et al. (2019) believed that natural disasters were the most severe threat in rural areas, with landslides being one of the major natural disasters that influenced the spatial reconstruction of rural settlements [21]. Additionally, some scholars have found that quality of life also influenced the spatial reconstruction of rural settlements. For example, Onyemelukwe (1980), Wieruck (2021), and Kasimis (2008) found that many peasant households left villages due to insufficient infrastructure, inadequate education resources, and fewer employment opportunities, relocating to places with better living conditions [72-74]. Cvetkovic (2009) found that some peasant households moved because they wanted a new way of life [60]. Social network relationships also affected the relocation behavior of peasant households. When peasant households first moved to a new place of residence, they were worried about being marginalized by the aboriginals. As they live there longer and longer, peasant households can slowly adapt to the diversity of the 
community $[75,76]$. Ethnic minority peasant households usually worry about language barriers and poor dietary habits after moving to the place of migration [77].

Based on existing literature studies and theoretical analyses [41,78-82], an initial SEM model of factors that influenced the intention of peasant households concerning the spatial reconstruction of rural settlements in mountainous areas was constructed (Figure 3). Interaction was assumed between the five latent variables: external attractions, geological disasters, internal impetus, production cohesion, and life cohesion. It was also assumed that more development opportunities, poor traffic conditions, the probability of geological disasters, and place attachment would influence the reconstruction intention of peasant households. The path coefficients of these five variables were fixed at 1.

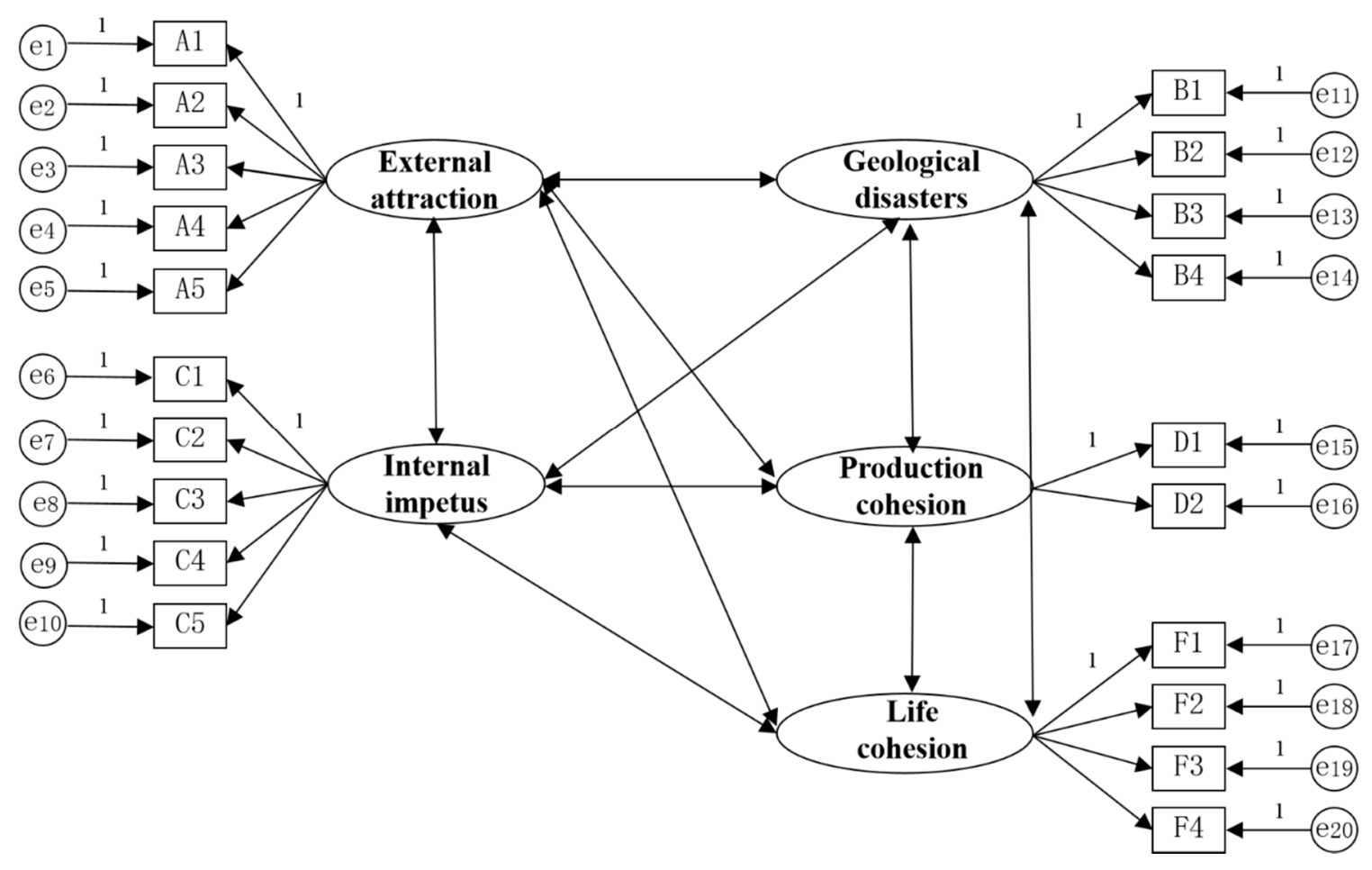

Figure 3. Initial SEM structural equation.

\subsubsection{The Models}

Structural equation modeling (SEM) is an essential statistical method for the quantitative study of modern behavior in social research. It integrates the factor analysis from traditional multivariable statistical analysis and the statistical approach of regression analysis from linear models. SEM can identify, estimate, and verify several causal models [83]. SEM, or the latent variable model, includes measurement and a structural model. The measurement model is composed of latent variables and observation variables. The relationship between reflective latent variables and manifest variables is usually expressed according to Equation (1), and the relationship between formative latent variables and manifest variables is usually expressed according to Equation (2):

$$
\begin{aligned}
& X=\Lambda_{x} \xi+\delta \\
& Y=\Lambda_{y} \eta+\varepsilon
\end{aligned}
$$

Here, $\varepsilon$ is not related to $\eta, \xi$, or $\delta$, while $\delta$ is not related to $\eta, \xi$, or $\varepsilon$. $X$ is the exogenous observation index, and $Y$ is the endogenous observation index. $\Lambda_{x}$ and $\Lambda_{y}$ are factor loads of the index variable $(\mathrm{x}, \mathrm{y}) . \delta$ and $\varepsilon$ are the measurement errors of the observed variables $\mathrm{X}$ and $Y$, respectively, while $\eta$ and $\xi$ are the exogenous latent variable and endogenous latent 
variable, respectively. SEM hypothesizes that there is no co-variation or causal relationship between latent variables (common factors) and the measurement errors.

The relationship between latent variables is usually expressed according to Equation (3):

$$
\eta=B \eta+\Gamma \xi+\zeta
$$

Here, $B$ is a coefficient matrix of $n \times n$ and denotes the relationship between endogenous latent variables. $\Gamma$ is a coefficient matrix of $n \times m$ and denotes the relationship of exogenous latent variables to the endogenous latent variables. $\zeta$ is the residual error of the SEM model and reflects the unexplained part of $\eta$ in the equation. Analysis of the models in this study was performed using Amos 22.0.

\section{Results}

\subsection{Descriptive Statistical Analysis of Respondents}

Among the 266 peasant households, 165 were willing to participate in the spatial reconstruction of rural settlements, accounting for $62.03 \%$. The remaining 101 were unwilling to participate in the spatial reconstruction of rural settlements, accounting for $37.97 \%$. This reflected that most peasant households had a strong inclination towards the spatial reconstruction of rural settlements for villages in the sampled regions (Xichang City, Miyi County, Puge County, and Yanyuan County). Among the 266 peasant households, most had an educational background of either illiteracy or primary school. Most respondents were in good physical condition. Males accounted for $61.28 \%$, and the average age was 44.35 years. Minority groups accounted for $67.67 \%$, with the highest proportion being the Yi ethnicity. Most peasant households (85.34\%) were engaged in agricultural activities. Overall, the village populations were mainly middle-aged males from minority groups with low educational backgrounds who were engaged in agricultural production activities (Table 2).

Table 2. Descriptive statistics of the respondents.

\begin{tabular}{|c|c|c|c|}
\hline Variable & Definition & Mean & Standard Deviation \\
\hline Gender & Respondents' gender $($ female $=0$, male $=1)$ & 0.39 & 0.488 \\
\hline Age & Respondents' age (in years) & 44.35 & 14.088 \\
\hline Education & $\begin{array}{c}\text { Respondents' education level (illiteracy }=0, \\
\text { primary school }=1, \text { junior middle school }=2, \\
\text { senior high school }=3, \text { junior college }=4, \\
\text { university and above }=5 \text { ) }\end{array}$ & 1.08 & 1.248 \\
\hline Health & $\begin{array}{l}\text { Respondents' physical health } \\
\text { (very good }=1, \text { good }=2, \text { general }=3 \text {, } \\
\text { not good }=4, \text { very bad }=5 \text { ) }\end{array}$ & 2.37 & 1.235 \\
\hline $\begin{array}{l}\text { Engaged in } \\
\text { agriculture }\end{array}$ & $\begin{array}{l}\text { Are you engaged in agriculture? } \\
\qquad(\text { yes }=1, \text { no }=0)\end{array}$ & 0.86 & 0.351 \\
\hline Ethnicity & $\begin{array}{c}\text { Respondents' ethnicity }(\mathrm{Han}=1, \mathrm{Yi}=2, \\
\text { Tibetan }=3, \text { other }=4)\end{array}$ & 1.71 & 0.518 \\
\hline
\end{tabular}

\subsection{Validity and Reliability}

First, reliability analysis was carried out on different layers of the questionnaire survey by using Cronbach's alpha. An $\alpha$ value greater than or equal to 0.6 indicates acceptable reliability [83]. It can be seen from Table 3 that Cronbach's $\alpha$ value for the general scale was 0.692 , which indicates good reliability. Furthermore, Cronbach's $\alpha$ values for the five scale layers were mainly $\geq 0.6$, indicating that the questionnaire had some consistency and stability. The structural validity of the questionnaire was verified by factor analysis. The $\mathrm{KMO}$ (Kaiser-Meyer-Olkin) value for the general scale was 0.812 , and the KMO values for the five layers of the scale were all higher than 0.5 , and the $p$-value was $0.000<0.01$. 
The Bartlett test of sphericity indicated that factor analysis was applied to the survey data. It can be seen from Table 4 that the principal factors that were screened from the factor analysis conformed to the theoretical structure entirely, and that the cumulative variance contribution rate was relatively high. This demonstrates that the questionnaire has good structural validity.

Table 3. Analysis of questionnaire reliability and validity.

\begin{tabular}{|c|c|c|c|c|c|c|}
\hline \multirow[b]{2}{*}{ Latent Variables } & \multirow[b]{2}{*}{ Observation Variables } & \multirow{2}{*}{$\begin{array}{l}\text { Cronbach's } \\
\text { Alpha }\end{array}$} & \multirow[b]{2}{*}{ KMO } & \multicolumn{3}{|c|}{ Bartlett's Test of Sphericity } \\
\hline & & & & $\begin{array}{l}\text { Approximate } \\
\text { Chi-Square }\end{array}$ & $\begin{array}{l}\text { Degree of } \\
\text { Freedom }\end{array}$ & $p$-Value \\
\hline External attraction & $\mathrm{A} 1, \mathrm{~A} 2, \mathrm{~A} 3, \mathrm{~A} 4, \mathrm{~A} 5$ & 0.936 & 0.903 & 2038.165 & 10 & 0.000 \\
\hline Geological disasters & B1, B2, B3, B4 & 0.828 & 0.795 & 396.079 & 6 & 0.000 \\
\hline Internal impetus & $\mathrm{C} 1, \mathrm{C} 2, \mathrm{C} 3, \mathrm{C} 4, \mathrm{C} 5, \mathrm{C} 6$ & 0.632 & 0.693 & 164.452 & 10 & 0.000 \\
\hline Production cohesion & D1, D2 & 0.939 & 0.500 & 404.238 & 1 & 0.000 \\
\hline Life cohesion & $\mathrm{F} 1, \mathrm{~F} 2, \mathrm{~F} 3, \mathrm{~F} 4$ & 0.515 & 0.659 & 59.858 & 6 & 0.000 \\
\hline \multicolumn{2}{|c|}{ Overall } & 0.692 & 0.812 & 3372.221 & 190 & 0.000 \\
\hline
\end{tabular}

Table 4. Factor loading matrix after rotation.

\begin{tabular}{|c|c|c|c|c|c|c|}
\hline & & \multicolumn{5}{|c|}{ Factor } \\
\hline & & 1 & 2 & 3 & 4 & 5 \\
\hline \multirow{5}{*}{ External attractions } & A15 & 0.657 & 0.121 & -0.095 & 0.097 & 0.320 \\
\hline & A2 & 0.924 & 0.035 & 0.157 & -0.072 & -0.205 \\
\hline & A3 & 0.926 & 0.061 & 0.171 & 0.007 & -0.223 \\
\hline & $\mathrm{A} 4$ & 0.930 & 0.077 & 0.165 & -0.044 & -0.196 \\
\hline & A5 & 0.930 & 0.049 & 0.182 & -0.021 & -0.204 \\
\hline \multirow{4}{*}{ Geological disasters } & B1 & 0.083 & 0.836 & 0.017 & -0.012 & -0.010 \\
\hline & B2 & 0.059 & 0.786 & 0.085 & 0.059 & 0.045 \\
\hline & B3 & 0.099 & 0.849 & 0.026 & -0.124 & -0.039 \\
\hline & $\mathrm{B} 4$ & 0.001 & 0.751 & 0.133 & -0.047 & -0.201 \\
\hline \multirow{5}{*}{ Internal impetus } & $\mathrm{C} 1$ & -0.017 & 0.075 & 0.617 & 0.113 & -0.170 \\
\hline & $\mathrm{C} 2$ & -0.001 & 0.190 & 0.600 & 0.102 & -0.133 \\
\hline & $\mathrm{C} 3$ & 0.277 & 0.002 & 0.725 & -0.032 & 0.217 \\
\hline & $\mathrm{C} 4$ & 0.130 & 0.000 & 0.591 & -0.080 & -0.015 \\
\hline & C5 & 0.150 & 0.015 & 0.530 & -0.140 & 0.000 \\
\hline \multirow{2}{*}{ Production cohesion } & D1 & -0.007 & -0.068 & -0.015 & 0.948 & 0.095 \\
\hline & D2 & -0.018 & -0.038 & 0.031 & 0.938 & 0.094 \\
\hline \multirow{4}{*}{ Life cohesion } & F1 & -0.195 & -0.051 & 0.051 & -0.158 & 0.607 \\
\hline & $\mathrm{F} 2$ & -0.235 & -0.140 & -0.114 & 0.148 & 0.603 \\
\hline & F3 & -0.208 & 0.007 & 0.232 & 0.208 & 0.461 \\
\hline & $\mathrm{F} 4$ & 0.076 & -0.010 & -0.193 & 0.369 & 0.632 \\
\hline Cumulative variance con & on rate & \multicolumn{5}{|c|}{$65.026 \%$} \\
\hline
\end{tabular}

\subsection{Fitting and Adaption of Models}

The initial model (Figure 2) was verified by survey data and revised according to correction indices. After three paths were added successively, the revised SEM paths were obtained (Figure 4). The two paths e6 $\leftrightarrow \mathrm{e} 7$ and $\mathrm{e} 1 \leftrightarrow \mathrm{e} 20$ passed the significance test and had positive values, indicating that transportation accessibility was positively correlated with the convenience of getting water, selection of living mode, and development opportunities. The new path e10 $\leftrightarrow$ e18 passed the significance test and had a negative value. This indicates that a stronger community cultural atmosphere made peasant households easier to contact and accept different dietary cultures. As a result, their dietary habits were more readily changed. 


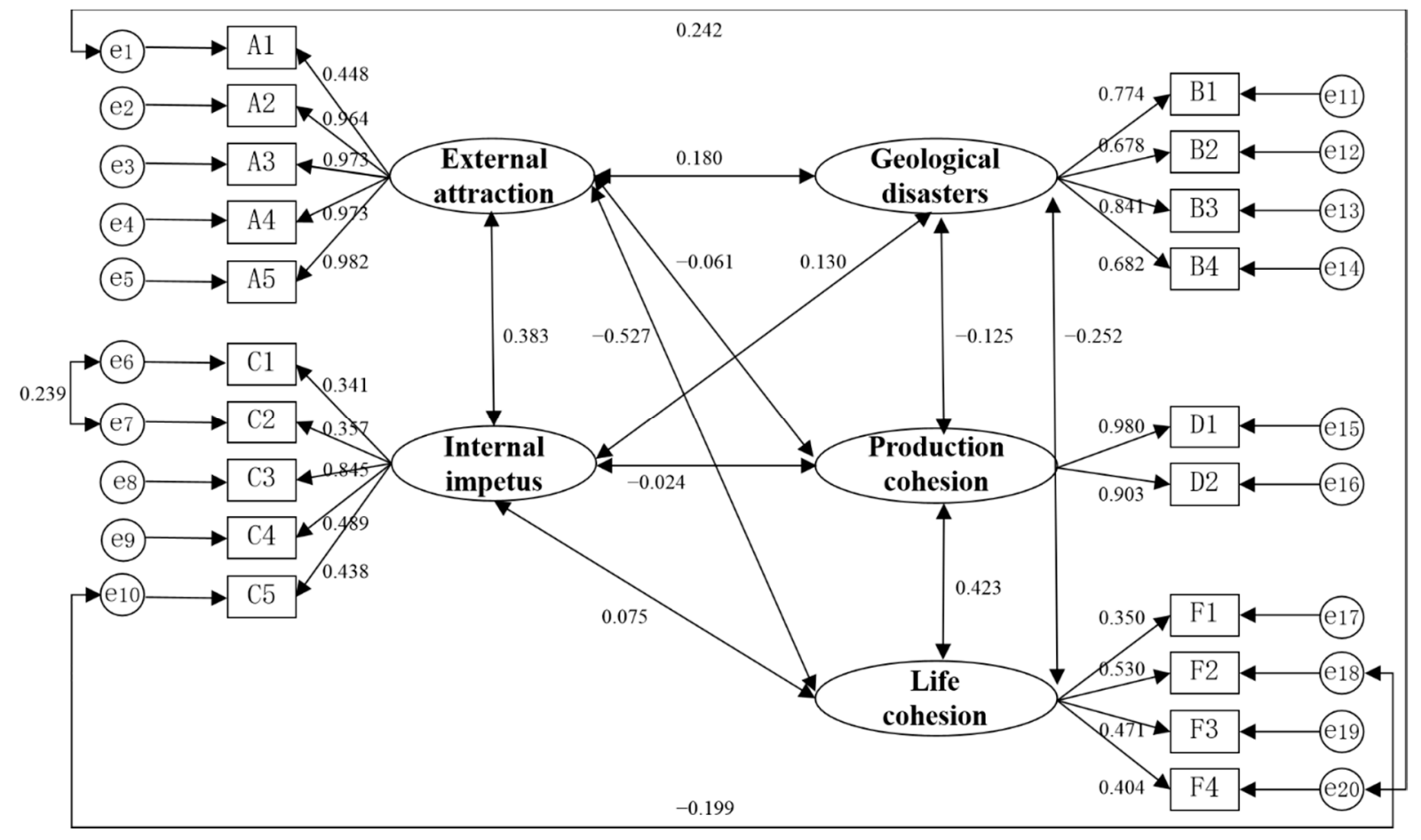

Figure 4. Revised path of the model.

During the fitting evaluation of an SEM model, a higher degree of fitting indicates that the model construction is more reasonable. In this study, the SEM of factors influencing peasant households' reconstruction intentions was verified by confirmatory factor analysis. The results (Table 5) demonstrate that among the absolute adaptation indices for the SEM model, $\chi^{2} / \mathrm{df}=1.592(<3), \mathrm{RMR}=0.024(<0.05)$, and RMSEA = $0.047(<0.05)$. Furthermore, the SEM fitting indices GFI, NFI, RFI, IFI, TLI, and CFI were all greater than 0.90, and PGFI, PNFI, and PCFI in the simple adaptation index were all higher than 0.50 . Therefore, all model indices conformed to the requirements, indicating the good fit of the model.

Table 5. Model adaptation indices.

\begin{tabular}{|c|c|c|c|c|}
\hline Evaluation Indic & & Fit Standard & Primary Model & Modified Model \\
\hline \multirow{4}{*}{ Absolute fit indices } & $\chi^{2 \backslash \mathrm{df}}$ & $\begin{array}{l}<3, \text { good } \\
<5, \text { accept }\end{array}$ & 1.789 & 1.592 \\
\hline & GFI & $>0.9$ & 0.902 & 0.916 \\
\hline & RMR & $<0.05$ & 0.024 & 0.024 \\
\hline & RMSEA & $\begin{array}{l}<0.05, \text { good } \\
<0.08 \text {, accept }\end{array}$ & 0.055 & 0.047 \\
\hline \multirow{5}{*}{ Incremental fit indices } & NFI & $>0.9$ & 0.918 & 0.928 \\
\hline & RFI & $>0.9$ & 0.902 & 0.913 \\
\hline & IFI & $>0.9$ & 0.962 & 0.972 \\
\hline & TLI & $>0.9$ & 0.954 & 0.966 \\
\hline & CFI & $>0.9$ & 0.962 & 0.972 \\
\hline \multirow{3}{*}{ Parsimonious fit indices } & PGFI & $>0.5$ & 0.688 & 0.685 \\
\hline & PNFI & $>0.5$ & 0.773 & 0.767 \\
\hline & PCFI & $>0.5$ & 0.810 & 0.803 \\
\hline
\end{tabular}

Note: GFI is goodness-of-fit index; RMR is root mean square residual; RMSEA is standardized root mean square residual; NFI is normed fit index; RFI is relative fit index; IFI is incremental fit index; TLI is Tacker-Lewis index; CFI is comparative fit index; PGFI is parsimony goodness-of-fit index; PNFI is parsimony-adjusted NFI; PCFI is parsimony-adjusted CFI. 


\subsection{Recognition of Driving Forces}

The non-standardized regression coefficient was calculated by the maximum likelihood method (Table 6). The standard deviations and critical values of the probability of geological disasters, poor traffic conditions, farming culture, and place attachment are blank because these five factors were set as fixed parameters in the initial modeling.

Table 6. The regression coefficient of path.

\begin{tabular}{|c|c|c|c|c|c|c|}
\hline & & Items & $\begin{array}{c}\text { Non- } \\
\text { Standardized } \\
\text { Estimate }\end{array}$ & $\begin{array}{l}\text { Standard } \\
\text { Error }\end{array}$ & $\begin{array}{c}\text { Critical } \\
\text { Ratio }\end{array}$ & $\begin{array}{c}\text { Standardized } \\
\text { Estimate }\end{array}$ \\
\hline A14 & $\leftarrow$ & External attraction & 1 & & & $0.448^{* * *}$ \\
\hline A2 & $\leftarrow$ & External attraction & 2.034 & 0.25 & 8.144 & $0.964^{* * *}$ \\
\hline A3 & $\leftarrow$ & External attraction & 2.11 & 0.258 & 8.166 & $0.973^{* * *}$ \\
\hline A4 & $\leftarrow$ & External attraction & 2.11 & 0.258 & 8.165 & $0.973^{* * *}$ \\
\hline A5 & $\leftarrow$ & External attraction & 2.12 & 0.259 & 8.184 & $0.982^{* * *}$ \\
\hline B1 & $\leftarrow$ & Geological disasters & 1 & & & $0.774^{* * *}$ \\
\hline B2 & $\leftarrow$ & Geological disasters & 0.877 & 0.083 & 10.532 & $0.678^{* * *}$ \\
\hline B3 & $\leftarrow$ & Geological disasters & 1.005 & 0.08 & 12.546 & $0.841^{* * *}$ \\
\hline B4 & $\leftarrow$ & Geological disasters & 0.984 & 0.093 & 10.596 & $0.682^{* * *}$ \\
\hline $\mathrm{C} 1$ & $\leftarrow$ & Internal impetus & 1 & & & $0.341^{* * *}$ \\
\hline $\mathrm{C} 2$ & $\leftarrow$ & Internal impetus & 1.008 & 0.234 & 4.306 & $0.357^{* * *}$ \\
\hline $\mathrm{C} 3$ & $\leftarrow$ & Internal impetus & 1.972 & 0.434 & 4.546 & $0.845^{* * *}$ \\
\hline $\mathrm{C} 4$ & $\leftarrow$ & Internal impetus & 1.273 & 0.295 & 4.312 & $0.489^{* * *}$ \\
\hline C5 & $\leftarrow$ & Internal impetus & 0.949 & 0.229 & 4.14 & $0.438^{* * *}$ \\
\hline D1 & $\leftarrow$ & Production cohesion & 1 & & & $0.980^{* * *}$ \\
\hline D2 & $\leftarrow$ & Production cohesion & 0.934 & 0.093 & 10.097 & $0.903^{* * *}$ \\
\hline $\mathrm{F} 1$ & $\leftarrow$ & Life cohesion & 1 & & & $0.350 * * *$ \\
\hline F2 & $\leftarrow$ & Life cohesion & 1.494 & 0.364 & 4.11 & $0.530^{* * *}$ \\
\hline F3 & $\leftarrow$ & Life cohesion & 1.208 & 0.306 & 3.943 & $0.471^{* * *}$ \\
\hline $\mathrm{F} 4$ & $\leftarrow$ & Life cohesion & 1.081 & 0.291 & 3.719 & $0.404^{* * *}$ \\
\hline
\end{tabular}

(1) Among the external attractions, the standardized regression coefficients of good medical conditions, sufficient water and power supply, convenient information acquisition, and a suitable living environment were all higher than 0.960 . This reflects that these factors had significantly positive effects on the reconstruction intention of peasant households. To seek better living conditions, peasant households were more willing to accept the spatial reconstruction of rural settlements. Among external attractions, the path coefficient of more development opportunities was fixed at 1 , and the standardized regression coefficient was 0.448 , indicating that development opportunities (e.g., employment and education) had positive impacts on the reconstruction intention of peasant households. However, development opportunities were not highly related compared with other external attraction factors.

(2) Among geological disasters, the path coefficient of the probability of geological disasters was fixed at 1 , and the standardized regression coefficient was 0.774 . The standardized regression coefficients of the frequency of geological disasters, the influence of geological disasters on crops, and economic loss caused by geological disasters were 0.678 , 0.841 , and 0.682 , respectively. Of these, B3 (the influence of geological disasters on crops) was the top factor that influenced the reconstruction intention of peasant households, while the other three factors also had relatively significant positive impacts on the reconstruction intention of peasant households. Most peasant households in surveyed villages had experienced geological disasters. They were mainly engaged in agricultural production, with crops forming their primary income source and survival foundation. They believed that geological disasters could affect crop outputs and even their houses, greatly influencing their current residence.

(3) For internal impetus, the standardized regression coefficients of a weak community cultural atmosphere, poor communication network, power shortages, and water shortages were $0.438,0.489,0.845$, and 0.357 , respectively. The path coefficient of poor traffic conditions was fixed at 1 , and the standardized regression coefficient was 0.341 . All these factors significantly influenced the reconstruction intention of peasant households. Specifically, 
power shortage was the primary influencing factor, followed by a poor communication network. This reflects that the imperfect communication networks and electronic devices in current residences brought great inconvenience to the daily life of peasant households. Peasant households had a stronger reconstruction intention if they had lower satisfaction with their current residential environment. Furthermore, the community cultural atmosphere had a slightly positive influence on the spatial reconstruction of rural settlements. Water shortages and poor traffic conditions had positive effects on the reconstruction intention of peasant households; however, these effects were minimal.

(4) Among the production cohesion factors, the path coefficient of farming culture was fixed at 1 , and the standardized regression coefficient was 0.980 . The standardized regression coefficient of pasture culture was 0.903 . This indicates that farming culture and pasture culture were significantly positively correlated with the reconstruction intention of peasant households. Peasants prefer places where they can plant crops and feed poultry, as they depend on the planting and breeding industries. When there was a more robust farming culture and pasture culture, peasant households were worried that there was not enough land for agricultural and poultry industries and had a stronger reconstruction intention.

(5) In the life cohesion factors, the path coefficient of place attachment was fixed at 1 , and the standardized regression coefficient $(0.350)$ was lower than for the other three factors. This indicates that place attachment was not highly correlated with the reconstruction intention of peasant households. The standardized regression coefficients of dietary habit, language, and living mode were $0.530,0.471$, and 0.404 , respectively. Of these, language, living mode, and place attachment positively affected the reconstruction intention of peasant households; however, these effects were small. Dietary habits was the top influencing factor of the reconstruction intention of peasant households. This was because most peasant households are minorities with unique dietary habits and are highly unwilling to change their current staple food. Dietary habits had a considerable positive influence on the reconstruction intention of peasant households.

\section{Discussion}

This study combined participatory rural appraisals with a structural equation model. It analyzed the influence of people's willingness on behavior choices from the perspective of peasant households to explore the driving force of behavior results. The SEM method is an important analysis tool in quantitative research. For conceptual indicators that are difficult to directly and accurately measure, such as psychology and society, the SEM model provides a method to account for measurement errors-using multiple indicators to reflect potential variables. This study method is more accurate and reasonable than the traditional regression methods and has many applications, such as psychology, management, and other related research. Scholars can design questionnaires according to their own research goals to study people's behavioral motivations.

This study obtained conclusions consistent with those of Garcia (2009), Pritchard (2012), and Wierucka et al. (2021). That is, that external attractions are important drivers of the spatial reconstruction of rural settlements. Specifically, places with better infrastructure, including good medical conditions and sufficient water and power supply, are more attractive to peasant households and result in a stronger reconstruction intention of peasant households. Additionally, the living environment is an important factor that people consider in choosing a residence. Indeed, people impose higher and higher requirements on their quality of life with improved economic levels in western developed countries. A suitable living environment is a premise and basis for a high quality of life $[74,84,85]$. Convenient information acquisition and more development opportunities help guarantee a high quality of life $[86,87]$. A different research conclusion of the present study compared to previous studies was that development opportunities (e.g., employment and education) had significantly positive effects on the reconstruction intention of peasant households, but these effects were not very significant. This may be related to implementing the rural revitalization strategic policy in the Panxi area in recent years. Increasing anti-poverty 
projects have been introduced in the Panxi area, which has provided more employment and education opportunities for local people. This may explain why local peasant households did not have a stronger intention to relocate to places with more development opportunities.

Many countries have researched the driving forces of place attachment in the spatial reconstruction of rural settlements. However, there have been few studies relating to place attachment in China. Place attachment is composed of local dependence (functional attachment) and local identity (emotional attachment) [88]. Barcus (2010) and Malik and Yoshida (2020) found that place attachment could promote the spatial reconstruction of rural settlements. One of the important factors that affected peasant households' intention to move to a better place was local attachment $[89,90]$. However, the present study found that although place attachment was one factor that peasant households considered in migration, it was not decisive. All respondents lived in mountainous areas in the Panxi area, where power shortages, geological diseases, and poor living conditions were common. As these places do not provide the ideal residential mode, peasant households had a low emotional and functional attachment to their current residential areas. It was interesting that life cohesion influenced peasant households' intentions relating to the spatial reconstruction of rural settlements the least, which was different from the research results of Deumert (2005) and Sami (2013) [91,92]. This may have been because, with the development of the social economy, local peasant households had increasing contact with people in other places and gradually began to become familiar with and accept the cultures, diets, and living modes of other ethnicities. Therefore, life cohesion was not the primary factor that peasant households considered during the spatial reconstruction of rural settlements.

The unique geological environment in mountainous regions intensifies unfairness and differences in the development among rural settlements. Rural settlements in mountainous regions develop more slowly and with more difficulty than those on plains. Suppose the spatial reconstruction of rural settlements in mountainous areas is unreasonable. In that case, it will inevitably result in or intensify the worsening of the ecological environment and geological disasters, thus posing an increased threat to the life and property of residents. Previous studies have found that the intention of peasant households plays an essential role in the spatial reconstruction of rural settlements $[12,40,93]$. Government-guided rural planning often fails if it does not respect the intention of peasant households and forces them to move $[28,94,95]$. Hence, exploring the driving forces for the spatial reconstruction of rural settlements by considering the intentions of peasant households can lead to the implementation of rural planning and construction that are closer to the ideal living mode of peasant households. This would encourage peasant households to take the initiative in reconstruction, thus decreasing conflicts between them and the government.

This study has made the following novel contributions: (1) The Panxi area in Sichuan Province, a typical mountainous region in China, was chosen as the study area to explore the driving forces of the spatial reconstruction of rural settlements in mountainous areas. (2) From the perspective of peasant households, this study explored the five driving forces of external attraction, internal impetus, geological disasters, production culture, and life culture in the spatial reconstruction of rural settlements in mountainous areas. (3) Place attachment was used as an influencing factor in peasant households' reconstruction intention. It was added to study the driving forces of the spatial reconstruction of rural settlements in mountainous areas. This study provides an important guide for the implementation of rural planning and construction in the Panxi area in the future. It can also provide references for the study of driving forces for spatial reconstruction of mountainous rural settlements in other cities or countries.

This study had certain limitations that can be addressed in future research. The spatial reconstruction of rural settlements is complicated and influenced by many factors. This study did not consider peasant households' unique features, family features, and policy perceptions. A supplementary questionnaire survey will investigate these factors. Additionally, future studies will explore the reconstruction mode of rural settlement spaces based on the identified driving forces. 


\section{Conclusions and Implications}

In this study, the driving forces for the spatial reconstruction of rural settlements in mountainous areas were explored by using the questionnaire survey data of rural families in the Panxi area of Sichuan Province, China, from 2017, and establishing an SEM. The following major conclusions were drawn:

(1) Among the 16 sampled villages in the Panxi area, most peasant households had a very strong intention towards the spatial reconstruction of rural settlements.

(2) Important factors that influenced the reconstruction intention of peasant households were infrastructure constructions (e.g., electronic facilities and medical conditions), the living environment, the convenience of information accessibility, the farming culture, the pasture culture, dietary habits, and geological disasters.

(3) Place attachment, living mode, language, traffic, water resources, and development opportunities slightly influenced the reconstruction intention of peasant households.

(4) Geological disasters were the main driving force for the spatial reconstruction of rural settlements in mountainous areas, while life cohesion had the least influence.

The spatial reconstruction of rural settlements is an inevitable change in conformance with social and economic development. Although the spatial reconstruction of rural settlements in mountainous areas faces various challenges, the extensive support of peasant households in mountainous areas proves it is the right time for rural space reconstruction. The occurrence of geological disasters poses an overwhelming threat to the safety of rural households in mountainous areas. The Chinese government has introduced a relocation policy for poverty-stricken peasant households living in deep mountains, such as those with many geological disasters, inconvenient transportation, limited information, and poor living conditions. By improving the infrastructure of the resettlement area, supporting education and medical facilities, and guiding the employment of peasant households, the government can attract rural households in mountainous areas to relocate to resettlement areas with better living conditions, such as central villages, central towns, or industrial parks. This model can promote rural revitalization; the furthering of plans for broader, coordinated urban-rural development; and land-use management policies. After peasant households in mountainous areas moved with government assistance, their original homesteads were demolished. The government adjusted the land suitable for farming to reclaim and return to farming through the transformation of villages and towns and the merging of villages and townships, dramatically improving land-use efficiency. The most important thing is that during the spatial reconstruction of rural settlements, governments should consider a combination of the specific local rural conditions, peasant households' reconstruction intentions, and important influencing factors for these households as the basis for rural planning and construction. Such spatial reconstruction of rural settlements via government guidance combined with peasant household participation would facilitate an efficient reconstruction process by showing respect for their intentions.

Author Contributions: Conceptualization, J.Z., S.C. and S.L.; methodology, H.Y. and M.H.; formal analysis, J.Z.; investigation, J.Z., M.H., H.Y. and S.L.; data curation, S.L. and J.Z.; supervision, H.Y.; writing-original draft preparation, J.Z.; writing-review and editing, H.Y., S.L. and S.C. All authors have read and agreed to the published version of the manuscript.

Funding: The research was funded by Sichuan Science and Technology Program (Grant No.2019YFS0467), the National Natural Science Foundation of China (Grant No.41671529), and Monitoring and Warning Program for Resources and Environment Carrying Capability in Sichuan Province (Grant No. ZXGH201709).

Institutional Review Board Statement: Not applicable.

Informed Consent Statement: Not applicable.

Data Availability Statement: Not applicable.

Acknowledgments: We thank the academic editors and anonymous reviewers for their kind suggestions and valuable comments. 
Conflicts of Interest: The authors declare no conflict of interest.

\section{References}

1. Li, N.; Jiang, S. Study on spatial pattern of rural settlements in Wuling Mountainous Area based on GIS. Wirel. Pers. Commun. 2018, 102, 2745-2757. [CrossRef]

2. Wang, F.; Yu, F.Y.; Zhu, X.H.; Pan, X.L.; Sun, R.M.; Cai, H.R. Disappearing gradually and unconsciously in rural China: Research on the sunken courtyard and the reasons for change in Shanxian County, Henan Province. J. Rural Stud. 2016, 47, 630-649. [CrossRef]

3. Hongbo, L.; Xiaolin, Z.; Qiyan, W.; Yahua, W. Characteristics and Mechanism of Rural Settlements Spatial Reconstruction in Developed Areas-A Case Study of Southern Jiangsu. J. Nat. Resour. 2015, 30, 591-603. (In Chinese)

4. Zang, Y.Z.; Liu, Y.S.; Yang, Y.Y.; Woods, M.; Fois, F. Rural decline or restructuring? Implications for sustainability transitions in rural China. Land Use Policy 2020, 94, 104531. [CrossRef]

5. Long, H.L.; Liu, Y.S. Rural restructuring in China. J. Rural Stud. 2016, 47, 387-391. (In Chinese) [CrossRef]

6. Woods, M. Rural Geography: Processes, Responses and Experiences in Rural Restructuring. In Rural Geography Processes Responses E Experiences in Rural Restructuring; SAGE Publications Ltd.: London, UK, 2011; Volume 7, pp. 494-496.

7. Li, H.B.; Zhang, X.L. Spatial extension in the context of urban and rural development: Village recession and reconstructio. Reform 2012, 1, 148-153. (In Chinese)

8. Long, H.L. Land consolidation and rural spatial restructuring. Acta Geogr. Sin. 2013, 68, 1019-1028. (In Chinese)

9. Long, H.L.; Tu, S.S. Theoretical thinking of rural restructuring. Prog. Geogr. 2018, 37, 581-590. (In Chinese)

10. Tang, C.; He, Y.; Zhou, G.; Zeng, S.; Xiao, L. Optimizing the spatial organization of rural settlements based on life quality. J. Geogr. Sci. 2018, 28, 685-704. [CrossRef]

11. Li, Y.; Fan, P.; Liu, Y. What makes better village development in traditional agricultural areas of China? Evidence from long-term observation of typical villages. Habitat Int. 2019, 83, 111-124. [CrossRef]

12. Iguchi, T.; Ito, K.; Kitagawa, I. Analysis of agriculture-forestry production and settlement promotion policies in rural areas (I) On the possibility of transfer into rural areas. Nihon Ringakkai Shi 1995, 77, 421-428.

13. Brown, B.; Perkins, D.D.; Brown, G. Place attachment in a revitalizing neighborhood: Individual and block levels of analysis. $J$. Environ. Psychol. 2003, 23, 259-271. [CrossRef]

14. Burholt, V.; Naylor, D. The relationship between rural community type and attachment to place for older people living in North Wales, UK. Eur. J. Ageing 2005, 2, 109-119. [CrossRef] [PubMed]

15. Olshansky, R.B.; Nakabayashi, I.; Ohnishi, K. Socioeconomic, policy, and planning aspects of the 2004 Niigata Ken Chuetsu earthquake. Earthq. Spectra 2006, 22, S163-S175. [CrossRef]

16. Azimi, N.; Asgary, A. Rural residents and choice of building earthquake-resistant house: Results of a choice experiment study. Environ. Hazards 2013, 12, 240-257. [CrossRef]

17. Giannakopoulou, S.; Kaliampakos, D. The social aspects of rural, mountainous built environment. Key elements of a regional policy planning. J. Cult. Herit. 2016, 21, 849-859. [CrossRef]

18. Aure, M.; Førde, A.; Magnussen, T. Will migrant workers rescue rural regions? Challenges of creating stability through mobility. J. Rural Stud. 2018, 60, 52-59. [CrossRef]

19. Li, C.; Li, S.; Feldman, M.W.; Li, J.; Zheng, H.; Daily, G.C. The impact on rural livelihoods and ecosystem services of a major relocation and settlement program: A case in Shaanxi, China. Ambio 2018, 47, 245-259. [CrossRef]

20. Ma, L.; Liu, S.; Niu, Y.; Chen, M. Village-scale livelihood change and the response of rural settlement land use: Sihe village of Tongwei County in Mid-Gansu Loess Hilly region as an example. Int. J. Environ. Res. Public Health 2018, 15, 1801. [CrossRef] [PubMed]

21. Vaculisteanu, G.; Niculita, M.; Margarint, M.C. Natural hazards and their impact on rural settlements in NE Romania-A cartographical approach. Open Geosci. 2019, 11, 765-782. [CrossRef]

22. Charlier, B. From the countryside to the city: Missing the Homeland among New Migrants near and in Ulaanbaatar. Inn. Asia 2020, 22, 127-147. [CrossRef]

23. Scholten, J.J. Physical geography and rural settlement planning in western Jamaica. Geol. Mijnb. 1983, 62, 653-658.

24. Applebaum, L.; Newman, D.; Margulies, J. Institutions and settlers as reluctant partners: Changing power relations and the development of new settlement patterns in Israel. J. Rural Stud. 1989, 5, 99-109. [CrossRef]

25. Vandsemb, B.H. Spontaneous rural migration in southern Sri Lanka-the migrants and the determinants of out-migration. Nor. Geogr. Tidsskr. 1997, 51, 127-143. [CrossRef]

26. Hosseini, S.B.; Faizi, M.; Norouzian-Maleki, S.; Karimi Azari, A.R. Impact evaluation of rural development plans for renovating and retrofitting of rural settlements. Environ. Earth Sci. 2015, 73, 3033-3042. [CrossRef]

27. Phokaides, P. Rural networks and planned communities: Doxiadis associates' plans for rural settlements in post-independence Zambia. J. Archit. 2018, 23, 471-497. [CrossRef]

28. Hitchcock, R.K.; Sapignoli, M.; Babchuk, W.A. What about our rights? settlements, subsistence and livelihood security among central Kalahari San and Bakgalagadi. Int. J. Hum. Rights 2011, 15, 62-88. [CrossRef]

29. Song, J.; Peng, B. Should We Leave? Attitudes towards Relocation in Response to Sea Level Rise. Water 2017, 9, 941. [CrossRef]

30. Toshchenko, Z.; Velikiy, P. The key meanings of the lifeworld of rural residents in Russia. Mir Ross. 2018, 27, 7-33. [CrossRef] 
31. Alam, A.; Miller, F. Slow, small and shared voluntary relocations: Learning from the experience of migrants living on the urban fringes of Khulna, Bangladesh. Asia Pac. Viewp. 2019, 60, 325-338. [CrossRef]

32. Ma, L.; Chen, M.; Che, X.; Fang, F. Farmers' rural-to-urban migration, influencing factors and development framework: A case study of sihe village of Gansu, China. Int. J. Environ. Res. Public Health 2019, 16, 877. [CrossRef]

33. FAO. Land and Water Bulletin 2: Planning for Sustainable Use of Land Resources towards a New Approach; Land and Water Development Division, FAO: Rome, Italy, 1995.

34. Ozbek, R.; Citil, E.; Gunduz, S. Determination of functional characteristics of rural settlements for sustainability of ecological belts and corridors with specific reference to the Istanbul case. J. Environ. Prot. Ecol. 2011, 12, 1058-1067.

35. Fujii, T.; Tarumi, A.; Fujiwara, M. Possibility of village sustainment and resource management by settlement in West Shikoku. Nihon Ringakkai Shi 2009, 91,391-397. [CrossRef]

36. Marpaung, B.O.Y. Socio-cultural impacts in the formation of urban village. In Proceedings of the 1st Annual Applied Science and Engineering Conference, AASEC 2016, in Conjunction with the International Conference on Sport Science, Health, and Physical Education, ICSSHPE 2016, Bandung, Indonesia, 18 November 2016, 1st ed.; Institute of Physics Publishing: Bandung, Indonesia, 2017; Volume 180.

37. Peng, L.; Lin, L.; Liu, S.; Xu, D.D. Interaction between risk perception and sense of place in disaster-prone mountain areas: A case study in China's Three Gorges Reservoir Area. Nat. Hazards 2017, 85, 777-792. [CrossRef]

38. Adger, W.N.; de Campos, R.S.; Codjoe, S.N.A.; Siddiqui, T.; Hazra, S.; Das, S.; Adams, H.; Gavonel, M.F.; Mortreux, C.; Abu, M. Perceived environmental risks and insecurity reduce future migration intentions in hazardous migration source areas. One Earth 2021, 4, 146-157. [CrossRef]

39. Wu, Z.; Penning, M.J.; Zeng, W.; Li, S.; Chappell, N.L. Relocation and social support among older adults in rural China. J. Gerontol. Ser. B Psychol. Sci. Soc. Sci. 2016, 71, 1108-1119. [CrossRef]

40. Baert, M.; Kervyn, M.; Kagou, A.D.; Guedjeo, C.S.; Vranken, L.; Mertens, K. Resettlement preferences from landslide prone areas in Cameroon: Willingness to move, reasons to stay. Land Use Policy 2020, 95, 103975. [CrossRef]

41. Ma, L.B.; Dou, H.J.; Xie, Z.L.; Guo, X.D. Research on rural settlement reconstruction model based on integration drivers and suitability evaluation. Trans. Chin. Soc. Agric. Eng. 2019, 35, 246-255. (In Chinese)

42. Gunzler, D.; Chen, T.; Wu, P.; Zhang, H. Introduction to mediation analysis with structural equation modeling. Shanghai Arch. Psychiatry 2013, 25, 390-394. [CrossRef]

43. United Nations (UN). Available online: https://www.ifad.org/en/investing-in-rural-people (accessed on 10 July 2021).

44. United Nations (UN). Available online: https:/ / www.ifad.org/documents/38714170/40324464/AR2017_fullreport_e_W.pdf/ 1a9f6c5b-f8dc-4318-98da-4530dd9ca575?t=1528996838000 (accessed on 10 July 2021).

45. Qu, D.Y. Safeguard the High Life. Available online: http://www.chinadaily.com.cn/a/202012/11/WS5fd2b3fea31024ad0ba9b2 1f.html (accessed on 10 July 2021).

46. Wang, C.; Huang, B.; Deng, C.; Wan, Q.; Zhang, L.; Fei, Z.H.; Li, H.Y. Rural settlement restructuring based on analysis of the peasant household symbiotic system at village level: A Case Study of Fengsi Village in Chongqing, China. J. Rural Stud. 2016, 47, 485-495. [CrossRef]

47. Liu, Y.S.; Liu, J.L.; Zhou, Y. Spatio-temporal patterns of rural poverty in China and targeted poverty alleviation strategies. J. Rural Stud. 2017, 52, 66-75. [CrossRef]

48. Xu, D.D.; Yong, Z.L.; Deng, X.; Liu, Y.; Huang, K.; Zhou, W.F.; Ma, Z.X. Financial Preparation, Disaster Experience, and Disaster Risk Perception of Rural Households in Earthquake-Stricken Areas: Evidence From the Wenchuan and Lushan Earthquakes in China's Sichuan Province. Int. J. Environ. Res. Public Health 2019, 16, 3345. [CrossRef]

49. Xu, Y.; Qiu, X.P.; Yang, X.T.; Lu, X.Y.; Chen, G.J. Disaster risk management models for rural relocation communities of mountainous southwestern China under the stress of geological disasters. Int. J. Disaster Risk Reduct. 2020, 50, 101697. [CrossRef]

50. Xinhuanet. Available online: http:/ / www.xinhuanet.com/2018-01/23/c_1122302786.htm (accessed on 10 July 2021).

51. Xue, K.J.; Guo, S.L.; Liu, Y.; Liu, S.Q.; Xu, D.D. Social Networks, Trust, and Disaster-Risk Perceptions of Rural Residents in a Multi-Disaster Environment: Evidence from Sichuan, China. Int. J. Environ. Res. Public Health 2021, 18, 2106. [CrossRef]

52. Qiang, M. Analysis of the Spatial Conflicts of the National Land and Its Influencing Factors. Master's Thesis, Institute of Mountain Hazards and Environment, Chinese Academy of Sciences, Chengdu, China, 2018.

53. Pan, G. A Study of Jewish Refugees in China (1933-1945). In The Push-Pull Theory and Motivations of Jewish Refugees; Shanghai Jiaotong University Press: Shanghai, China, 2019; pp. 123-125. [CrossRef]

54. Gao, Y.; Chen, G.; Shen, M. Scattered rural settlements and development of mountainous regions in Western Sichuan, China. Wuhan Univ. J. Nat. Sci. 2007, 12, 737-742. [CrossRef]

55. Ayeb-Karlsson, S.; Kniveton, D.; Cannon, T. Trapped in the prison of the mind: Notions of climate-induced (im)mobility decision-making and wellbeing from an urban informal settlement in Bangladesh. Palgrave Commun. 2020, 6, 20551045. [CrossRef]

56. Teweldebrihan, M.D.; Pande, S.; McClain, M. The dynamics of farmer migration and resettlement in the Dhidhessa River Basin, Ethiopia. Hydrol. Sci. J. 2020, 65, 1985-1993. [CrossRef]

57. Karemera, D.; Oguledo, V.I.; Davis, B. A gravity model analysis of international migration to North America. Appl. Econ. 2000, 32, 1745-1755. [CrossRef]

58. Morrison, P.S.; Waldegrave, C. Welfare reform and the intra-regional migration of beneficiaries in New Zealand. Geoforum 2002, 33, 85-103. [CrossRef] 
59. Yu, W.; Lu, X.; Wang, E. Rural land reforms and villagers' preferences for urban settlement: A case study of Shandong Province, China. Growth Change 2020, 51, 1259-1276. [CrossRef]

60. Cvetkovic, A. The integration of immigrants in northern Sweden: A case study of the municipality of Strömsund. Int. Migr. 2009, 47, 101-131. [CrossRef]

61. Flynn, M.; Kay, R. Migrants' experiences of material and emotional security in rural Scotland: Implications for longer-term settlement. J. Rural Stud. 2017, 52, 56-65. [CrossRef]

62. Peng, Y.; Zhu, X.; Zhang, F.; Huang, L.; Xue, J.; Xu, Y. Farmers' risk perception of concentrated rural settlement development after the 5.12 Sichuan Earthquake. Habitat Int. 2018, 71, 169-176. [CrossRef]

63. Hamed-Troyansky, V. Becoming Armenian: Religious conversions in the late imperial South Caucasus. Comp. Stud. Soc. Hist. 2021, 63, 242-272. [CrossRef]

64. Hassendeen, S. Analysis of the weliwewa and maththala settlement schemes under the hambantota integrated rural development programme (Hirdep). Nor. Geogr. Tidsskr. 1983, 37, 159-170. [CrossRef]

65. Black, R.; Adger, W.N.; Arnell, N.W.; Dercon, S.; Geddes, A.; Thomas, D. The effect of environmental change on human migration. Glob. Environ. Chang. 2011, 21, S3-S11. [CrossRef]

66. Yang, R.; Liu, Y.; Long, H.; Qiao, L. Spatio-temporal characteristics of rural settlements and land use in the Bohai Rim of China. J. Geogr. Sci. 2015, 25, 559-572. [CrossRef]

67. Kaloko, F.R. African rural settlement patterns. Ekistics. Probl. Sci. Hum. Settl. 1983, 50, 459-462.

68. Hearn, G.J.; Hart, J.R. Settlements and slides: A large landslide case study from the central Cordillera of the Philippines. Q. J. Eng. Geol. Hydrogeol. 2019, 53, 62-73. [CrossRef]

69. Prescott, M.F.; Dobbie, M.F.; Ramirez-Lovering, D. Green infrastructure for sanitation in settlements in the global south: A narrative review of socio-technical systems. Sustainability 2021, 13, 2071. [CrossRef]

70. Filippova, V. Adaptation of the indigenous peoples to climate change effects in Yakutia: Gender aspects. Polar Sci. 2020, 26. [CrossRef]

71. Garakani, S.A.; Lak, A.; Niyasati, M. Toward sustainable development in post-flood relocation of rural settlements in Iran. Int. J. Disaster Resil. Built Environ. 2020, 11, 359-377. [CrossRef]

72. Onyemelukwe, J.O. Settlement structure as sociocultural constraints on Nigerian rural development (service provision). Ekistics 1980, 47, 353-355.

73. Kasimis, C. Survival and expansion: Migrants in Greek Rural Regions. Popul. Space Place 2008, 14, 511-524. [CrossRef]

74. Wierucka, A. Negotiating better futures-migration of Huaorani youth in rural Ecuador. J. Youth Stud. 2021. [CrossRef]

75. Valdivia, C.; Dozi, P.; Jeanetta, S.; Flores, L.Y.; Martínez, D.; Dannerbeck, A. The impact of networks and the context of reception on asset accumulation strategies of Latino newcomers in new settlement communities of the midwest. Am. J. Agric. Econ. 2008, 90, 1319-1325. [CrossRef]

76. de Hoon, M.; Vink, M.; Schmeets, H. On the move again? Residential trajectories of refugees after obtaining asylum in the Netherlands. Popul. Space Place 2021, 27. [CrossRef]

77. Turner, L.M.; Wessel, T. Upwards, outwards and westwards: Relocation of ethnic minority groups in the oslo region. Geogr. Ann. Ser. B Hum. Geogr. 2013, 95, 1-16. [CrossRef]

78. Patricio, E.P.; Francisco, J.M.; Juan de Dios, O. Microeconomic Formulation and Estimation of a Residential Location Choice Model: Implications for the Value of Time. J. Reg. Sci. 2003, 43, 771-789. [CrossRef]

79. Yadav, R.; Pathak, G.S. Young consumers' intention towards buying green products in a developing nation: Extending the theory of planned behavior. J. Clean Prod. 2016, 135. [CrossRef]

80. Chen, H.; Zhao, L.; Zhao, Z. Influencing factors of farmers' willingness to withdraw from rural homesteads: A survey in zhejiang, China. Land Use Policy 2017, 68, 524-530. [CrossRef]

81. Zhang, Z.; Wen, Y.; Wang, R.; Han, W. Factors influencing rural households' willingness of centralized residence: Comparing pure and nonpure farming areas in China. Habitat Int. 2018, 73, 25-33. [CrossRef]

82. Xiao, L.; Shi, P.; Lin, T.; Chen, N.; Huang, S. Rural Morphology and Forces Driving Change in Rapidly Urbanizing Areas: A Case Study in Fujian, China. Int. J. Environ. Res. Public Health 2021, 18, 4590. [CrossRef]

83. Yu, B.; Wang, J.Y.; Liao, Y.; Wu, H.Y.; Wong, A.B. Determinants Affecting Purchase Willingness of Contractors towards Construction and Demolition Waste Recycling Products: An Empirical Study in Shenzhen, China. Int. J. Environ. Res. Public Health 2021, 18, 4412. [CrossRef]

84. Garcia, C. The role of quality of life in the rural resettlement of Mexican immigrants. Hisp. J. Behav. Sci. 2009, 31, 446-467. [CrossRef]

85. Pritchard, B.; Argent, N.; Baum, S.; Bourke, L.; Martin, J.; McManus, P.; Sorensen, A.; Walmsley, J. Local—If possible: How the spatial networking of economic relations amongst farm enterprises aids small town survival in rural Australia. Reg. Stud. 2012, 46, 539-557. [CrossRef]

86. Arif, G.M.; Hamid, S. Urbanization, city growth and quality of life in Pakistan. Eur. J. Soc. Sci. 2009, 10, $196-215$.

87. Ramoroka, T. The misnomer of rural-urban migration in South Africa and implications on townships' development. Int. J. Econ. Financ. Stud. 2020, 12, 551-562. [CrossRef]

88. Wenyue, T. The effects of ancient village residents' place attachment on their relocation willingness under the background of tourism development: A case study of Wuyuan ancient villages. Bus. Manag. J. 2014, 36, 124-132. (In Chinese) 
89. Barcus, H.R.; Brunn, S.D. Place elasticity: Exploring a new conceptualization of mobility and place attachment in rural america. Geogr. Ann. Ser. B Hum. Geogr. 2010, 92, 281-295. [CrossRef]

90. Malik, A.; Yoshida, T. Residents' Willingness to Move from Slum to Rusunawa in Tangerang City, Greater Jakarta: Dimensions of Place Attachment in Housing Relocation. J. Asia Jpn. Res. Inst. Ritsumeikan Univ. 2020, 2, 92-108. [CrossRef]

91. Deumert, A.; Inder, B.; Maitra, P. Language, informal networks and social protection: Evidence from a sample of migrants in Cape Town, South Africa. Glob. Soc. Policy 2005, 5, 303-328. [CrossRef]

92. Sami, K. The interaction of environment, space and the human being in rural alevi culture-The case of two villages. Bilig 2013, 67, 169-194. [CrossRef]

93. Zhang, L.; Zhao, Y.; Zhang, X.; Du, H. Effect Mechanisms of Peasant Relocation Decision-making Behaviours in the Process of Rural Spatial Restructuring: The case of Hotan region, China. Sustain. Cities Soc. 2020, 63, 102429. [CrossRef]

94. Ahmed, K.G.; El-Gizawy, L. The dilemma of sustainability in the development projects of rural communities in Egypt-The case of New Gourna. Int. J. Sustain. Dev. Plann. 2010, 5, 407-429. [CrossRef]

95. Mendoza Sammet, A. Policy-induced involuntary resettlement: The case of the Mexican Rural Cities Policy. Impact Assess. Proj. Apprais. 2017, 35, 53-64. [CrossRef] 